\title{
THE RE-INSTATEMENT OF HYDROPUNTIA MONTAGNE (GRACILARIACEAE, RHODOPHYTA)
}

\author{
Michael J. Wynne
}

\section{Summary}

The red algal generic name Hydropuntia Montagne (1842: 7), typified by H. urvillei Mont., is reinstated and circumscribed to include Polycavernosa Chang \& Xia (1963: 120) and a number of its species. Up to now Hydropuntia has been regarded as a heterotypic synonym of Gracilaria Greville (1830) nom. cons. but is shown to be the earliest validly published name for those species separated from Gracilaria on the basis of both spermatangial and cystocarpic criteria.

Generic delimitation within the red algal family Gracilariaceae Nägeli (1847) [Gracilariales Fredericq \& Hommersand (1989a)] has been in a state of some flux in recent years. For example, Gracilariopsis Dawson (1949), based on G. sjoestedtii (Kyl.) Daws., was taxonomically segregated from Gracilaria Greville (1830: liv) nom. cons. based on the nature of the gonimoblast, which in Gracilariopsis does not form nutritive filaments and is composed of small cells with dense contents, in contrast to these character states in Gracilaria. Later Papenfuss (1967) presented arguments to merge Gracilariopsis within Gracilaria. More recently Fredericq and Hommersand $(1988,1989 \mathrm{~b})$ called for the separation of these two genera, based on differences in reproductive morphologies.

Polycavernosa is another related genus that was described by Chang and Xia (1963) with a new species, $P$. fastigiata as the type. Although some doubt has been expressed (e.g., Bird and McLachlan, 1982, 1984) whether this genus is sufficiently distinct from Gracilaria, later workers, such as Chang and Xia (1976), Zhang and Xia (1984), Fredericq and Norris (1985), and Xia and Abbott (1985, 1987), provided additional taxonomic data to maintain these genera as distinct. Xia and Abbott (1987) stated that the spermatangial conceptacles in Polycavernosa are not merely a modification of the Verrucosa-type (sensu Yamamoto, 1978), but they have a clustered rather than a continuous arrangement and they have a different ontogenetic origin. Most recent authors have supported the recognition of Polycavernosa (e.g., Tseng, 1983; Norris, 1985; Rodriguez, 1986b; Silva et al., 1987; Lawson and John, 1987). Some species of Gracilaria have been transferred into Polycavernosa and new species have been described (Fredericq and Norris, 1985; Rodriguez, 1986a, 1988; Xia and Abbott, 1987). $\mathrm{Xia}$ and Abbott (1987) have summarized the criteria employed to distinguish Polycavernosa from Gracilaria. These differences are based on the origin and location of spermatangia and the time of appearance and the origin of the cystocarp, with species compared in terms of their male and cystocarpic characteristics. Also, elaborate basal absorbing filaments are present in the cystocarp of Polycavernosa, but such filaments are absent in Gracilaria.

The circumscription of Polycavernosa now includes the species P. urvillei (Montagne) Xia \& Abbott (1987), which is the type of Hydropuntia Montagne (1842), from Torres Strait, northeastern Australia. The type specimen is in PC. Recent collections from Malaysia by Doty and figured in Xia and Abbott (1987, fig. 7) closely resemble this species as depicted by Montagne (1845, pl. 1, fig. 1). Xia and Abbott (1987) reported the presence of compound spermatangial crypts ("caves") in their material, characteristic of Polycavernosa. Hydropuntia has been regarded as a heterotypic synonym of Gracilaria (Kylin, 1956), but the name is the earliest validly published one to encompass those species separated from Gracilaria and presently recognized in Polycavernosa. Hence, I wish to re-instate Hydropuntia and propose the following transfers:

Hydropuntia albornozii (Rodriguez) Wynne comb. nov.

Basionym: Polycavernosa albornozii Rodríguez, Ernstia 46: 1, fig. 1. 1988.

Hydropuntia changii (Xia \& Abbott) Wynne comb. nov.

Basionym: Polycavernosa changii Xia \& Abbott, Phycologia 26: 407, figs. 3, 11. 1987.

Hydropuntia cornea (J. Agardh) Wynne comb. nov.

Basionym: Gracilaria cornea J. Agardh, Sp. Gen. Ord. Alg. 2(2): 598. 1852.

\footnotetext{
1 Herbarium and Dept. of Biology, University of Michigan, Ann Arbor, MI 48109-1048, U.S.A.
} 
This western Atlantic species, called Gracilaria debilis (Forsskål) Børgesen (1932) by Taylor (1960), was shown by Fredericq and Norris (1985) to conform to Polycavernosa and called P. debilis (Forsskål) Fredericq \& J. Norris. Bird et al. (1986) examined the type (in C) of Fucus debilis Forsskål (1775) from Yemen and other material (in L) from the Red Sea. Although the material lacked spermatangial and cystocarpic features, they concluded that Forsskål's name did not apply to the western Atlantic species and that its correct name, using Taylor's generic concept, was Gracilaria cornea J. Agardh.

Hydropuntia corymbiata (Rodriguez) Wynne comb. nov.

Basionym: Polycavernosa corymbiata Rodríguez, Emstia 38: 23, figs. 12-16. 1986a.

Hydropuntia crassissima (Crouan \& Crouan) Wynne comb. nov.

Basionym: Plocaria crassissima P. \& H. Crouan in Schramm \& Mazé, Essai Alg. Guadeloupe. 20. 1865.

Gracilaria crassissima (P. \& H. Crouan) P. \& H. Crouan in Schramm \& Mazé, 1866. Polycavernosa crassissima (P. \& H. Crouan) Fredericq \& J. Norris, 1985.

Hydropuntia dentata (J. Agardh) Wynne comb. nov.

Basionym: Gracilaria dentata J. Agardh, Gen. Sp. Ord. Alg. 2(2): 603.1852.

Polycavernosa dentata (J. Agardh) Lawson \& John, 1987.

Hydropuntia divergens (Xia \& Abbott) Wynne comb. nov.

Basionym: Polycavernosa divergens Xia \& Abbott, Phycologia 26: 409, figs. 4, 9, 12.1987.

Hydropuntia fastigiata (Chang \& Xia) Wynne comb. nov.

Basionym: Polycavernosa fastigiata Chang \& Xia, Studia Marina Sinica 3: 120, pl. 1, figs. 1-11; pl. 2, figs. 1-6. 1963.

Hydropuntia fisheri (Xia \& Abbott) Wynne comb. nov.

Basionym: Polycavernosa fisheri Xia \& Abbott, Phycologia 26: 411, figs. 5, 13. 1987.

Hydropuntia henriquesiana (Hariot) Wynne comb. nov.

Basionym: Gracilaria henriquesiana Hariot, J. Bot., Paris, sér. 2, 1: 162, fig. s.n. 1908.

Polycavernosa henriquesiana (Hariot) Chang \& Xia, 1963.

Steentoft (1967) and Lawson and John (1987) have regarded this species to be distinct from $\mathrm{Hy}$ dropuntia dentata, with which it has been confused (e.g., Ohmi, 1968). Lawson and John (1987) indicated that spermatangial plants relate this species to Polycavernosa (=Hydropuntia).

Hydropuntia multifurcata (Børgesen) Wynne comb. nov.

Basionym: Gracilaria multifurcata Børgesen, Det. Kgl. Danske Vid. Selsk., Biol. Medd. 21(9): 42, figs. $15,16.1953$.

Polycavernosa multifurcata (Børgesen) Chang \& Xia, 1963.

Hydropuntia percurrens (Abbott) Wynne comb. nov.

Basionym: Polycavernosa percurrens Abbott, Taxonomy of economic seaweeds 2: 146, fig. 13. 1988a.

Hydropuntia ramulosa (Chang \& Xia) Wynne comb. nov.

Basionym: Polycavernosa ramulosa Chang \& Xia, Studia Marina Sinica 3: 122, pl. 1, fig. 13; pl. 11 , fig. 7. 1963.

Hydropuntia subtilis (Xia \& Abbott) Wynne comb. nov.

Basionym: Polycavernosa subtilis Xia \& Abbott, Phycologia 26: 413, figs. 6, 14. 1987.

Hydropuntia tsudae (Abbott \& Meneses) Wynne comb. nov.

Basionym: Polycavernosa tsudae Abbott \& Meneses in Meneses \& Abbott, Micronesica 20: 195, figs. $10-13.1987$. 
Hydropuntia vanbosseae (Abbott) Wynne comb. nov.

Basionym: Polycavernosa vanbosseae Abbott, Taxonomy of economic seaweeds 2: 152, figs. 1, 2. 1988b.

The genus Corallopsis Greville (1830) is a heterotypic congener of Gracilaria. Its lectotype, $C$. salicornia (C. Ag.) Grev. [basionym: Sphaerococcus salicornia C. Agardh 1822: 232] =G. salicornia (C. Ag.) Dawson (1949), has been recently investigated (Xia, 1987; Meneses and Abbott, 1987), and the evidence supports its inclusion within Gracilaria.

\section{Acknowledgments}

I thank Dr. John A. West for providing me with literature.

\section{Literature Cited}

Abbott, I. A. 1988a. Some species of Gracilaria and Polycavernosa from Thailand. Pp. 137-150. In: I. A. Abbott (ed.), Taxonomy of economic seaweeds with reference to some Pacific and Caribbean species, vol. 2. Calif. Sea Grant College Prog., Univ. Calif., La Jolla, California.

- 1 1988b. Some species of Gracilaria and Polycavernosa from the Siboga Expedition. Pp. 151156. In: I. A. Abbott (ed.), Taxonomy of economic seaweeds with reference to some Pacific and Caribbean species, vol. 2. Calif. Sea Grant College Prog., Univ. Calif., La Jolla, California.

Agardh, C. A. 1822. Species algarum ..., vol. 1, pt. 2. Berling, Lund.

Agardh, J. G. 1852. Species genera et ordines algarum ..., vol. 2, pt. 2. C. W. K. Gleerup, Lund.

Bird, C. J. and J. McLachlan. 1982. Some underutilized taxonomic criteria in Gracilaria (Rhodophyta, Gracilariaceae). Bot. Marina 25: 557-562.

- $\longrightarrow$ and 1984. Taxonomy of Gracilaria: Evaluation of some aspects of reproductive structure. Hydrobiologia 116/117: 41-46.

- E. C. de Oliveira and J. McLachlan. 1986. Gracilaria cornea, the correct name for the western Atlantic algae hitherto known as G. debilis (Rhodophyta, Gigartinales). Can. J. Bot. 64: 20452051.

Børgesen, F. 1932. A revision of Forsskål's algae mentioned in Flora Aegyptiaco-Arabica and found in his Herbarium in the Botanical Museum of the University of Copenhagen. Dansk Bot. Arkiv $8(2): 1-15$, pl. 1 .

- 1953. Some marine algae from Mauritius. Additions to the parts previously published, V. Det. Kgl. Danske Vid. Selsk., Biol. Medd. 21(9): 1-62, 3 pls.

Chang, C. F. and B. M. Xia. 1963. Polycavernosa, a new genus of the Gracilariaceae. Studia Marina Sinica 3: 119-126, 2 pls. and - 1976. Studies on Chinese species of Gracilaria. Studia Mar. Sinica 12: 91-163.

Dawson, E. Y. 1949. Studies on northeast Pacific Gracilariaceae. Allan Hancock Foundation Publ., Occas. Pap. 7.

Forsskål, P. 1775. Flora aegyptiaco-arabica. ... Post-mortem auctoris edidit Carsten Niebuhr. Möller, Kjøbenhavn.

Fredericq, S. and M. Hommersand. 1988. The status of Gracilariopsis (Gracilariaceae, Rhodophyta). J. Phycol. 24(Suppl.): 10. [Abstr.]

and 1989a. Proposal of the Gracilariales, ord. nov. (Rhodophyta) based on an analysis of the reproductive development of Gracilaria verrucosa (Hudson) Papenfuss. J. Phycol. 25. (In press.)

and - 1989b. The comparative morphology and taxonomic status of Gracilariopsis Dawson (Gracilariales, Rhodophyta). J. Phycol. 25. (In press.)

and J. N. Norris. 1985. Morphological studies on some tropical species of Gracilaria Grev. (Gracilariaceae, Rhodophyta): Taxonomic concepts based on reproductive morphology. $\mathrm{Pp}$. 137-155. In: I. A. Abbott and J. N. Norris (eds.), Taxonomy of economic seaweeds with reference to some Pacific and Caribbean species, Calif. Sea Grant College Prog., Univ. Calif., La Jolla, California.

Greville, R. K. 1830. Algae britannicae... MacLachlan \& Stewart, Edinburgh.

Hariot, P. 1908. Les algues de San Thome (côte occidentale d'Afrique). J. Bot., Paris, sér. 2, 1: 161164.

Kylin, H. 1956. Die Gattungen der Rhodophyceen. C. W. K. Gleerup, Lund. 
Lawson, G. W. and D. M. John. 1987. The marine algae and coastal environment of tropical West Africa, 2nd ed. Beihefte z. Nova Hedw. 93.

Meneses, I. and I. A. Abbott. 1987. Gracilaria and Polycavernosa (Rhodophyta) from Micronesia. Micronesica 20: 187-200.

Montagne, J. F. C. 1842. Prodromus generum specierumque phycearum novarum, in itinere ad polum Antarcticum Regis Ludovici Philippi Jussu ab illustri Dumont d'Urville peracto collectarum. . . . Gide, Paris.

1845. Plantes cellulaires. In: J. S. C. Dumont d'Urville, Voyage au Pôle Sud et dans l'Oceanie sur les corvettes l'Astrolabe et la Zélée ... pendant ... 1837-1840. Botanique, vol. 1. Gide \& J. Baudry, Paris.

Nägeli, C. 1847. Die neuern Algensysteme. Zürich. (In Kommission bei F. Schulthess.)

Norris, J. N. 1985. Gracilaria and Polycavernosa from the Caribbean and Florida: Key and list of the species of economic potential. Pp. 101-113. In: I. A. Abbott and J. N. Norris (eds.), Taxonomy of economic seaweeds with reference to some Pacific and Caribbean species., Calif. Sea Grant College Prog., Univ. Calif., La Jolla, California.

Ohmi, H. 1968. A descriptive review of Gracilaria from Ghana, West Africa. Bull. Fac. Fish., Hokkaido Univ. 19: 83-86, 2 pls.

Papenfuss, G. F. 1967. Notes on algal nomenclature-V. Various Chlorophyceae and Rhodophyceae. Phykos 5: 95-105.

Rodríguez de Rios, N. 1986a. El genero Polycavernosa Chang y Xia (Gracilariaceae, Rhodophyta) en Venezuela, con descripción de una nueva especie. Ernstia 38: 12-31.

. 1986b. Sobre la verdadera identidad de la llamada Gracilaria verrucosa (Hudson) Papenfuss en Venezuela. Ernstia 38: 32-39.

. 1988. Polycavernosa albornozii sp. nov. (Rhodophyta, Gigartinales, Gracilariaceae), una nueva especie del sur del Caribe. Ernstia 46: 1-7.

Schramm, A. and H. Mazé. 1865. Essai de classification des algues de la Guadeloupe (ed. 1). Imprimerie du Gouvernment, Basse-Terre, Guadeloupe.

— and 1866. Essai de classification des algues de la Guadeloupe (ed. 1a). Imprimerie du Gouvernment, Cayenne, Guyane française.

Silva, P. C., E. G. Meñez and R. L. Moe. 1987. Catalog of the benthic marine algae of the Philippines. Smithsonian Contrib. Mar. Sci. 27.

Steentoft, M. 1967. A revision of the marine algae of São Thomé and Principe (Gulf of Guinea). $J$. Linn. Soc. (Bot.) 60: 99-146, 2 pls.

Taylor, W. R. 1960. Marine algae of the eastern tropical and subtropical coasts of North America. Univ. Michigan Press, Ann Arbor.

Tseng, C. K. (ed.). 1983. Common seaweeds of China. Science Press, Beijing.

Xia, B. M. 1987 ["1986”]. On Gracilaria salicornia (C. Agardh) Dawson. Chin. J. Oceanol. Limnol. 4: $100-105$. and I. A. Abbott. 1985. The genus Polycavernosa Chang et Xia (Gracilariaceae, Rhodophyta): A comparison with Gracilaria Grev. and a key to the species. Pp. 157-162. In: I. A. Abbott and J. N. Norris (eds.), Taxonomy of economic seaweeds with reference to some Pacific and Caribbean species, vol. 2. Calif. Sea Grant College Prog., La Jolla, California. and - 1987. New species of Polycavernosa Chang \& Xia (Gracilariaceae, Rhodophyta) from the western Pacific. Phycologia 26: 405-418.

Yamamoto, H. 1978. Systematic and anatomical study of the genus Gracilaria in Japan. Mem. Fac. Fish., Hokkaido Univ. 25: 97-152.

Zhang, J. (olim Chang, C. F.) and B. Xia. 1984. Some problems in the taxonomy of Chinese species of Gracilaria (Rhodophyta). Hydrobiologia 116/117: 59-62. 